\title{
人工污染戋場における拮抗放線菌の導入と ナス半身萎ちょう病の抑制効果について
}

\author{
草刚眞一**・岡田清嗣**・瓦谷光男 $* *$ ・ \\ 嘉儀 隆**・田中 寛** \\ Shin'ich KUSAKARI**, Kiyotugu OKADA**, Mituo KaWARATANI**, \\ Takashi KAGI** and Yutaka TANAKA** : \\ Suppression of Verticillium wilt of egg plants \\ by Streptomyces sp. $(\mathrm{C}-26)$ in infested soil*
}

\begin{abstract}
Summary
Verticillium wilt disease of eggplants was decreased by the addition of antagonistic actinomycetes strain C-26 (Streptomyces sp.) with crab shell meal in infested greenhouse soil. The addition of crab shell meal in soil (1t/10a) increased the population density of actinomycetes. Density of actinomycetes strain $\mathrm{C}-26$ was maintained above $10^{7} \mathrm{cfu} / \mathrm{g}$ soil for 47 days by the addition of crab shell meal in soil. Verticillium disease of eggplants was reduced $79 \%$ with addition of antagonistic actinomycetes and crab shell meal, and $12 \%$ with the addition of crab shell meal only.
\end{abstract}

緒

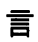

拮抗微生物を土壌に導入し発病を抑制しょうとする 試みは古くから知られているが, 土壌中における拮抗 菌の密度維持が難しく成功した例は少ない。しかし, 土壤に有機質資材を施用し, 土壤中に生存する拮抗微 生物数を増加させ防除に成功した例や，特定の有機質 資材の施用によって発病抑制する報告は認められ る, ${ }^{1,2,3)}$ 筆者らは, 土壤中より Verticillium dahliaeに対 し拮抗性を有する放線菌を数種分離した。これらの拮 抗菌のうちオガクズなど有機質資材で培養可能な菌株 を増殖し土壌中に導入したところ, 土壤中で短期間の 密度維持が可能で, この期間中においてナス半身萎调 病の発病が抑制された。拮抗微生物による防除では, 土䀶中における微生物の増殖が重要であるが, 本研究 では, 土猿中での放線菌密度変化と発病の抑制効果に ついての知見が得られたので報告する。

\section{実験材料および方法}

\section{放線菌の分離}

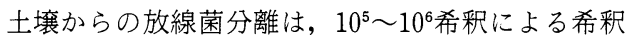
平板法により行った。分離用培地としてアルブミン寒 天培地を用いた。 $V$. dahliae に対する拮抗性検定は, $V$. dahliaeの分生胞子を懸濁したPDA 平板培地に分 離菌株を接種し, $25^{\circ} \mathrm{C} て ゙ 5$ 日間培養後, 放線菌コロニー 周辺の生育阻止帯形成により行った。

\section{放線菌の大量培養}

$V$. dahliae に対して拮抗力が認められた放線菌のう

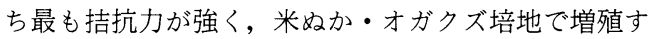
るCー26 菌(第 1 図) の大量増殖をおこなった。大量 増殖用の培地は, オガクズ：米ぬかを $3: 1$ の混合し たものを用いた。培養は, $500 \mathrm{ml}$ の培養コルベンを用 いて $28^{\circ} \mathrm{C} て ゙ 60$ 日間行い, 培地上が小豆色の胞子で覆 われる程度増殖したものを供試した。

\section{放線菌密度の測定}

土壌中の放線菌密度は, 放線菌に対して選択性をも

\footnotetext{
* 本論文の一部は, 日本植物病理学会関西部会（1989.10.27 富山市）で発表した。

** 大阪府農林技術センター 1990 年 1 月 25 日受理
} 


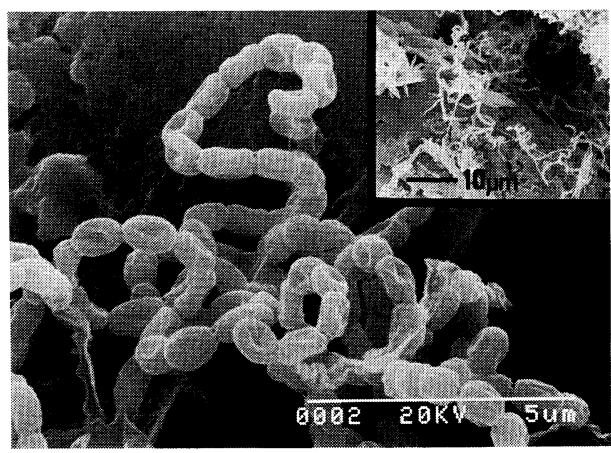

第 1 図走査電子顕微鏡による拮抗放線菌 C -26 (Streptomyces sp.) の形態

オガクズ培養菌をオスミウム酸 $2 \%$ 蒸気固定, 金 蒸着後, 日立 $\mathrm{S}$ - 530 型走査電子顕微鏡により観察し た。

たせるためアルブミン培地にシクロヘキシミド 50 ppm 添加したものを供試し, 希釈平板法により調査し た。また，土壌に導入した放線菌 C -26 の密度は，ア ルブミン寒天培地にシクロヘキシミド $100 \mathrm{ppm} セ$ ファロスポリン $50 \mathrm{ppm}$ を添加したものを分離培地と した希釈平板法により分離し,コロニー数を測定した。 放線菌 C -26 は, 分離培地で黄色の色素を生じ, コロ ニー周辺が黄色となることを利用し，他の放線菌から 識別した。

\section{土壤中への有機物施用と放線菌密度の変動}

土壌へ混和する有機質資材としてカニガラ, 乾燥牛 䔬, 大豆力又肥料を供試し, 土壤（農林技術センター 圃場より採取)に所定量を混和後，ワグナーポット (1) 5,000 a）に入れ，温室内において灌水管理（2 日おき に $100 \mathrm{ml} /$ ポットを灌水) を行った。

煵場試験は, 泉佐野市上之郷のナス栽培農家固場 (施 設栽培）で行った。固場へは, カ二ガラ, 牛䔬を所定 量施用し，慣行によるナス栽培を行い，経時的にナス 根圏より土猿を採取，微生物分離を行った。

\section{污染圑場の作成}

ナス半身萎调病污染圃場は, $1.5 \mathrm{~m} \times 2.0 \mathrm{~m}$ のコン クリート枠内に作成した。接種源は, PDA 平板培地に 接種後 $30^{\circ} \mathrm{C} 14$ 日間培養し,培地上で十分菌核を形成し た菌そうを用いた。コンクリート試験枠へは，枠あた りペトリ皿 20 枚分の菌そうをミキサーにより摩砕し たものを $10 l$ のイオン交換水に懸濁し，接種した。

\section{拮抗菌の土壤導入と半身萎调病の発病率}

放線菌 C -26 の半身萎调病抑制効果は, 污染戒場に オガクズ・米ぬか培養したC－26，カニガラを添加し， 経時的に発病率を調べる方法によって検討した。
土壌へのカニガラ添加は，拮抗菌の導入と同時に 行った。污染圃場へのナスの移植は，拮抗菌導入 4 日 後に行い, 本葉 5 葉の接き木（ヒラナス台）苗を供試 した。

\section{実 験 結 果}

\section{1.土袞中への有機質施用と土壤放線菌密度の変動}

ワグナーポットを用いて有機質資材の土蟶施用と微 生物変動を調査した。供試した有機質資材いずれにつ いても施用後, 土壤微生物数（全微生物数）の増加が 認められた。放線菌については, カニガラ $1 \mathrm{t} / 10 \mathrm{a} て ゙$ 施 用 14 日後に $6.5 \times 10^{7}$ 個/g soil に達し, 最も密度が高 くなった。しかし, カニガラ $2 \mathrm{t} / 10 \mathrm{a}$ 区では, 一次的に $8.0 \times 10^{6}$ 個 $/ \mathrm{g}$ soil 程度まで増加が認められたが，その 後 $1.8 \times 10^{6}$ 個 $/ g$ soil に減少した。大豆かす肥料施用区 (300 kg/10 a)，乾燥牛䔬施用区（1t/10 a）は，いず れも全微生物数の増加傾向を示したが, 放線菌の顕著 な増加傾向は認められなかった（第 2 図）。

現地のナス栽培圃場においてカニガラを $10 \mathrm{a}$ あた り $1 \mathrm{t}, 2 \mathrm{t}$ 施用し微生物数の変化を調べたところ, 施用 後 35 日後で $1 \mathrm{t}$ 区では, 全微生物数 $3.85 \times 10^{8} / \mathrm{g}$ soil に対して, 放線菌数 $7.5 \times 10^{7}, 2 \mathrm{t}$ 区で全微生物数

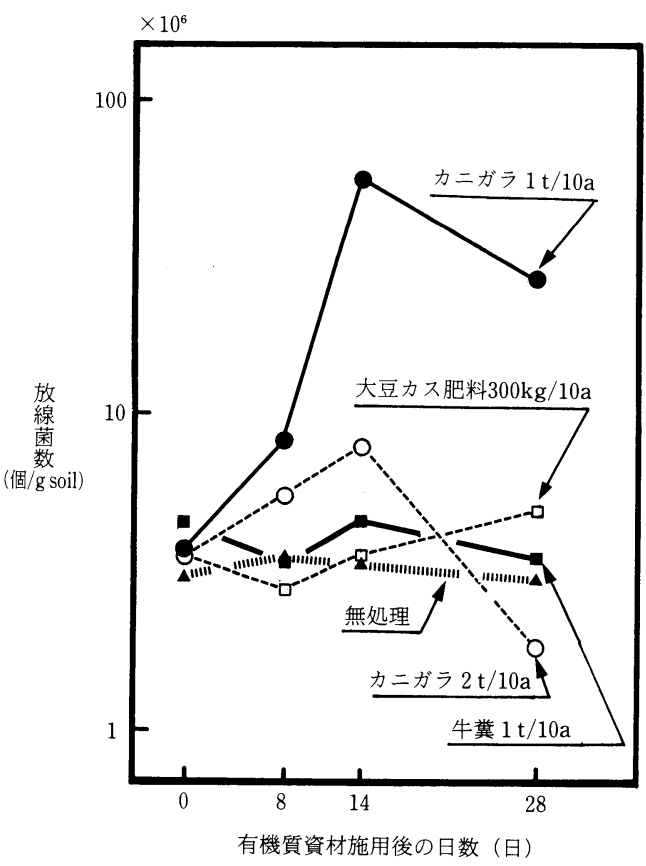

第 2 図土壤中への有機質資材の施用と放線菌密度 ポット内の土袞に供試有機質資材を施用，所定の期 間経過後に土壤を採取し, 希釈平板法により放線菌 数を測定した。 
$1.42 \times 10^{7} / \mathrm{g}$ soil に対して $9.2 \times 10^{7} / \mathrm{g}$ soil となったの に比較し, 無処理区では $2.40 \times 10^{7} / \mathrm{g}$ soil に対して, 放線菌数は $1.3 \times 10^{7} / \mathrm{g}$ soil と低くなった。

\section{2 . 放線菌 $\mathrm{C}-26$ の土壤導入と土㙵中での増加}

ナス半身萎ちょう病菌に対して拮抗性を示す放線菌 $\mathrm{C}$-26 (Streptomyces sp.) を培養し, 土壤中に導入後 の密度変化を調査した。放線菌 C -26 は，オガクズ・ 米又カ ( $3: 1)$ 培地で 90 日間培養したものを供試し た。土壌にオガクズ培養菌を $\left(300 \mathrm{~g} / \mathrm{m}^{2}\right)$ 導入 10 日後 には， $2.3 \times 10^{7} / \mathrm{g}$ soil の密度であったが，その後，密 度は減少し， 24 日後では $9.6 \times 10^{5} / \mathrm{g}$ soil に減少した。 しかし，カニガラを施用 $(1 \mathrm{t} / 10 \mathrm{a})$ 施用した区では, 土堛導入後の放線菌 $\mathrm{C}-26$ 密度は上昇し, 20 日後では $7.8 \times 10^{7} / \mathrm{g}$ soil まで上昇が認められ, 47 日後において $3.2 \times 10^{6} / \mathrm{g}$ soil の密度を維持した（第 3 図）。

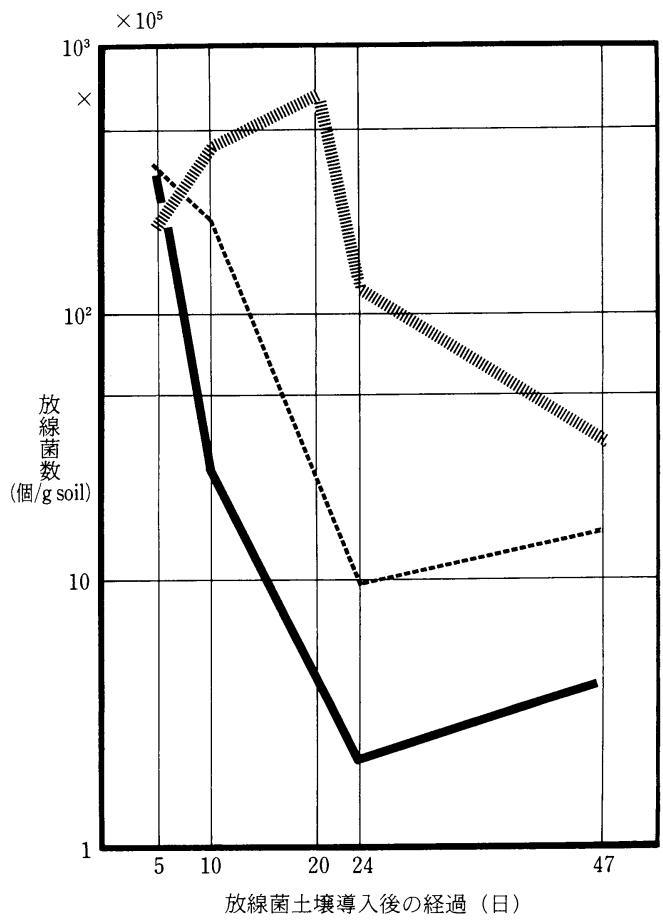

第 3 図試験圃場における放線菌 $(C-26)$ の密度 土壤に放線菌を導入後経時的に土壤を採種し, 放線 菌密度を調查した。放線菌 C一26の計数は, シクロ ヘキシミド $100 \mathrm{ppm}$, セファロスボリン $50 \mathrm{ppm}$ 。添加 アルブミン寒天培地で行った。

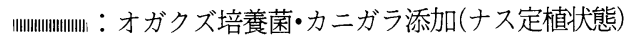

.......... : オガクズ培養菌のみ

：液体培養菌
3. ナス半身萎ちょう病污染土壌への放線菌 C -26 導入と発病率の変動

コンクリート枠内の污染戋場にオガクズ・米ヌカ培 養した放線菌 C-26 を接種，カニガラを 10 a あたり 1 $\mathrm{t}$ となるよう施用したのち, ナスを移植し，その後の発 病株率を調査した。対照区（カニガラ，拮抗菌を無添 加）では，ナス移植 22 日後から発病が認められ，47日 後には $100 \%$ に達したのに比較し，カニガラを施用し た区では, 32 日後で初発を認め, 36 日後の発病株率で 71\%，60日後には 100\%としだいに増加した。

カニガラと拮抗菌を導入した区では, ナス移植 36 日 後に初発を認めたが, 47 日後の発病株率は $21.0 \%$ と最 も低く, その後 60 日後の発病率も平均 $64 \%$ と低く なった。栽培 47 日後の発病株率は, 無添加区抢よび力 二ガラのみの施用区で $93 \%$ であったのに比較し，拮抗 菌導入区では $21 \%$ と低い発病株率を維持した。しか し, 拮抗菌導入区でもその後発病株率は上昇し，60日 後で $71 \%$ に達した（第 4,5 図）。

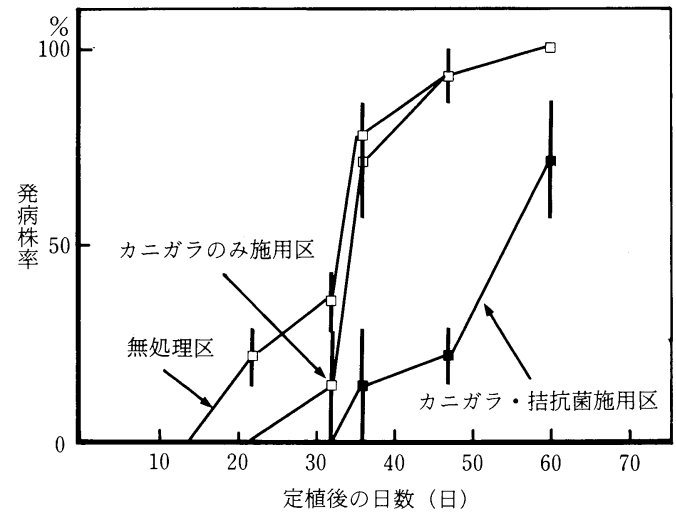

第 4 図拮抗放線菌の土㙵導入とナス半身萎ちょう 病の発病率（人工污染固場試験）

ナス苗を定植後，14，22，32，36，47，60日に発病 株率を調査した。

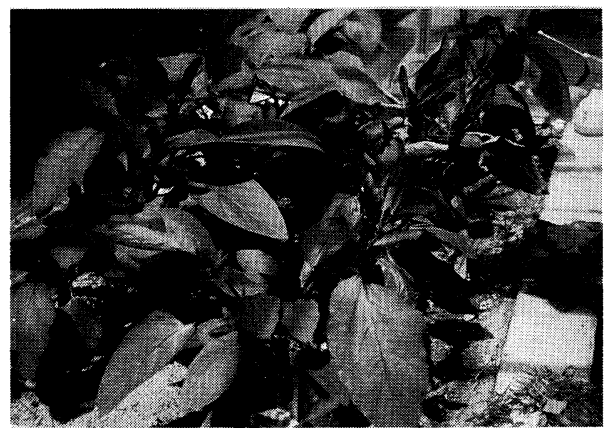

第 5 図試験区におけるナス半身萎ちょう病の発生状況 写真左側の列が拮抗菌導入区, 右側の列は無処理区

(葉が黄化萎调している)。 


\section{考察}

拮抗菌を土壤に導入して発病抑制効果を検討する場

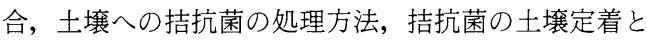
その後の増殖が問題となることが指摘されている Mitchell, R?!，土壤にキチンを添加することにより 土鉙中の拮抗放線菌を増殖させ，Fusarium 属菌によ る病害の抑制に成功している。駒田 ${ }^{2}$ は土壌にカニガ ラを添加することにより，キュウリの割病が抑制でき るとしている。筆者らの試験結果から，ポットおよび 戋場においてカニガラを施用したところ土壌中の放線 菌密度が増加することが確認され, Mitchell らの報告 同様，キチン質を含むカニガラ施用が土畩中の放線菌 増殖に効果のあることがわかった。とくに，10 a あた り $1 \mathrm{t}$ 施用した場合にその増加が著しく, 施用 20 日後 に $10^{7}$ の密度に達していた。また, 土壤へのカ二ガラ施 用は土壌中に生息する放線菌同様, 人工的に導入した 放線菌（C-26）についても増殖効果のあることがわ かった。オガクズ培養した拮抗放線菌 C -26 は, $7.8 \times$ $10^{7}$ 個/g soil まで増殖しており，試験を実施した 47 日 間にわたって $10^{6}$ の密度維持が可能であった。

カニガラを施用して導入した放線菌の密度維持をは かった土壌にナスを定植しナス半身萎ちょう病の発生 状況を調査したところ,無処理区に比べ初発が 14 日遅 く 47 日後の発病株率も $21 \%$ と低くなった。カニガラ のみを施用した区における発病株率についても，無処 理区よりやや低くなっており，カニガラ施用が本病の 発病をやや抑制すること, 拮抗菌の添加がさらに発病 抑制に効果的であることがわかった。

土壤伝染性病害では, 土壤中の微生物の密度を高め ることによっても発病抑制効果のあることが知られて いる。導入した放線菌 C -26 によるナス半身萎ちょう 病の発病抑制効果が拮抗菌のどのような作用によるの かは今後の検討課題である。

土壤中に放線菌を導入し病害防除する試みは, Ebben $ら^{6)}$ の報告, 中国の事(例7)が知られている。Marois $ら^{8)}$ は, ナス苗の根圏に拮抗菌を導入することで半 身萎ちょう病の防除が可能であると報告している。拮 抗菌の土㙵導入は長期間の密度維持など問題のあるこ とが指摘されているが，本研究の結果から適当な有機
資材を組み合わすことによって比較的短期間であれば 導入した拮抗菌の密度維持が可能であることが確認さ れた。今後，密度を更に長期間維持できる方法，およ び，土壤への導入方法の検討が課題であると考えられ る。

\section{摘要}

V. dahliaeに対して拮抗性のある放線菌 C -26（Streptomyces sp.) をオガクズ・米ぬか培地で培 養し，カニガラとともに人工污染土壌中に導入したと ころ，ナス半身萎ちょう病の発病抑制効果が認められ た。試験戋場に導入した放線菌の増殖は，カ二ガラを 施用した区において認められ，導入後 28 日において $10^{7}$ 個/g soil の密度に達し，47日後においても106個/ g soil の密度維持が可能であった。カニガラのみを施 用した区において発病抑制効果が認められたが，拮抗 菌を導入した区ではさらに発病抑制効果が高く，ナス 定植後 47 日後で対照, 無添加区の発病株率 $93 \%$ に対 し，21\%の低率に抑制した。

\section{引用文 献}

1) Mitchell. R. (1963) Phytopathology 53: 1068 -1071 .

2 ）松田明（1978）関東東山病虫研報 25：1 -4 .

3 ）松田 明（1981）植物防疫 32:231-237.

4 ) Cook, R.J. and Baker, K.F. (1983). The nature and practice of biological control of plant pathogens, APS, Minnesota, USA pp. 299-300.

5 ) 鈴木直治 (1966) 土と微生物（土壌微生物研究 会編)，岩波書店 東京 $\mathrm{pp} 201$.

6 ) Ebben, M.H. and Spencer, D.M. (1978). Ann. Appl. Biol. 89 : 103-106.

7 ) Cook, R.J. and Baker, K.F. (1983). The nature and practice of biological control of plant pathogens, APS, Minnesota, USA. PP. 50-51.

8 ) Marois, J.J., Johnston, S.A., Dunn, M.T. and Papavizas, G.C. (1982). Plant Disease 66: 1166 -1168 . 